\title{
College English Network Teaching and Learning Model Oriented by Critical Thinking Problems through Community of Practice
}

\author{
Li Wei \\ Liaoning Police Academy, Dalian, China
}

\begin{abstract}
Critical thinking is a kind of higher-levelled thinking model which emphasizes the following skills as conceptualizing, applying, analyzing, synthesizing, and evaluating information gathered from or generated by observation, experience reflection, reasoning, or communication. Critical thinking is also an important skill for the modern college students to master and apply in their study, research and future profession. This kind of skill can be trained and developed in any kind of educational patterns. Formal and informal English teaching and learning is an effective and practical approach. Relying on the information technology and communicative tool, three-stepped college English network teaching and learning model oriented by critical thinking problems through community of practice has been applied in Liaoning Police Academy for a couple of years. This three-stepped model includes: design and release of pre-class central questions, conducting inclass group collabrative learning through discussion and exploration, and carrying out after-class network reflective learning through accomplishing Viewpoint Composition or Reflective Diary. These three steps of teaching and learning centre around exploring, discussing, and answering 10 critical thinking questions advanced by English teachers' community of practice. After this unique and effective training program, most of college students are passionate for discussing and exploring those deep-levelled questions rather than repeating or imitating those simple and unchallenging questions, and hence, their critical thinking skills are enhanced to a perfect realm. English teachers should remember that an important purpose of teaching English is to develop students' critical thinking skill through putting forward sufficient questions covering language and cultural issues.
\end{abstract}

Index Terms - critical thinking, community of practice, three-stepped College English teaching and learning model

\section{INTRODUCTION}

In the book of Developing a Thinking Skills curriculum, Beyer emphasized that our graduates should be able to make well-reasoned decisions, solve problems skillfully, and make carefully thought out judgments about the worth, accuracy, and value of information, ideas, claims, and propositions. (Beyer, 1988) It is evident that the purpose of the education is not to make students grasp amounts of knowledge, but to help them master bountiful skills to analyze the problems with logical and critical thinking to judge their particular qualities and features, solving the problems in the end individually or collectively.

Among various thinking skills, critical thinking competence has been widely acknowledged as the core and indispensable one contributing to the creative and comprehensive development of the educated. Critical thinking training is a long and complex process based on universal intellectual values that transcend subject matter divisions: clarity, accuracy, precision, consistency, relevance, sound evidence, good reasons, depth, breadth, and fairness. It requires the educated master the basic skill of reasoning covering purpose, assumptions, concepts, empirical grounding, reasoning leading to conclusions, implications and consequences, objections from alternative viewpoints, and frame of reference.

College English teaching effects has the positive relative relationship with English teachers' critical thinking skill. In recent years, academic experts home and abroad began to focus on the condition of teachers' critical thinking skill and advocate that teacher preparation curriculum should attach to the importance of developing their own skills. Some researchers probed into its training approaches, such as case study, log method, and network discussion. The training on students' critical thinking skill through college English teaching and learning, however, hasn't been further explored and practiced. The paper mainly discusses the approaches and methods to train and develop students' critical thinking abilities through network college English teaching and learning pattern oriented by critical problems.

\section{Theoretical Study of Critical Thinking Concept And Its Combination with Network College English} TEACHING

\section{A. The Analysis of Critical Theory and Critical Thinking}


John Dewey (1859-1952) converted the descriptions of the processes of thinking into educational theory, who argued that quality education should go beyond memorizing facts to teach the processes of learning. Under the guidance of this educational concept, inquiring minds and questioning spirits are admired and promoted in the modern classroom. The modern philosophers of education have advanced Dewey's ideas that development of rational thinking should be a primary goal of schools.

Cognitive psychologists used observation as a primary research technique to advance the theory that cognitive processes develop based on experience. Vygotsky has recently amplified and classified the important relationship of experience, sicial relationships, and learnig. (Vygostsky, 1978) Philosopher Richard Paul clarified the field of critical thinking in Dimensions of Thinking: A passionate drive for clarity, accuracy, and fair-mindedness, a fervor for getting to the bottom of things, to the deepest root issues, for listening, sympathetically to opposite points of view, a compelling drive to seek out evidence, -----. (Paul, 1988) The National Council for Excellence in Critical Thinking defines critical thinking as follows: it is the intellectually desciplined process of actively and skillfully conceptualizing, applying, analyzing, synthesizing, and evaluating information gathered from, or generated by, observation, experience, reflection, resoning, or communicaiton, as a guide to belief and action.Critical thinking can be seen as having two components: a set of information and belief generating and processing skills and abilities; and the habit, based upon intellectural commitment, of using those skills and abilities to guide behavior.

\section{B. The Speciality of Critical Thinking in Higher Education and College English Teaching}

The main form of critical thinking is dialogue and self-reflection. The concept of dialogue derives from ancient Greece, and the concept of self-reflection from ancient oriental countries. The Dialogue Education contradicting with Monologue Educaiton came into popularity gradually. The real pitfall of the modern educaiton is that one authoritative monologue education substitutes for classical education characteristic of free dialogue education. (Cheng \& Xia, 2012) One of the speciality of higher education lies in the introduction of scientific research into teaching and learning process As a result, the goal of the higher education is to train the students' scientific spirits and creative thinking habits, possessing some certain self-study abilities so as to update their knowledge and improve their capabilities in the future professions. (Cheng \& Kang, 2010)

As to the Chinese college English teaching, most of English teachers don't have abundant crititical thinking abilities, which mainly attributes to seveal domestic elements restricting their CT development: the Chinese traditional cultures have been cultivating these English teachers, influencing their growth in characters and values. They learn to obey their parents and teachers with few discussions and ambiguous evaluations. English teaching objectives and contents always put linguistic skills training as the first priority, setting a very small proportion on the humnaistic educaiton promoting CT development, (Hu \& Sun, 2006) which results in the poor improment in CT abilities for teachers and students. In fact, the present popular college English teaching model featured by teacher-center, vocabulary, grammar and simple structure teaching, five-skill training cannot challenge English teachers' cognitive skills or promote their improvement in faculty of thinking.

\section{The Analysis of Community of Practice}

Community of Practice, firstly advanced by Jean Lave and Etienne Wenger, refers to a group of people connected with each other based upon the common interests and shared capabilities in the practical activities. (Wenger, 2002)This group of people shares their learning experience and knowledge in informal and creative forms so as to examine the problems appeared in this learning team with specific perspective and search for the solutions to the problems creatively. As a matter of fact, Community of Practice is the term of Situational Cognition Education with its emphasis on knowledge construction, meaning negotiation, and team members' cooperation. There are three core elements for this community including the common domain, the common community, and the common practice. This community of practice is not only a community with common ideals and interests, but, above all, a practical community characterized by mutual engagement, joint enterprise and shared repertoire. (Ruan, 2014)

\section{Construction And Practice of College English Teaching And LeARning Pattern Oriented By CRITICAL PROBLEMS THROUGH COMMUNITY OF PRACTICE}

\section{A. Construction of College English Teaching and Learning Community of Practice}

Based on the basic principles of community of practice, the author established English teaching community and English learning community. English teaching community named after Sharing \& Improving Online Teaching Community is mainly made up of 10 English teachers from five universities and English Learning community titled with Growing-up Online Learning Community is composed of 78 students from 7 universities. These two community members have common domain. The author relies on QQ communicative platform to set up 10 learning groups according to their different ideals and interests. These 10 learning groups conduct English topic reading and information sharing in their favourite fields. Therefore, the previous big class is divided into 10 interest groups who can accomplish teacher's pre-learning tasks and in-class activities. Similarly, the teaching community is divided into 5 groups with different teaching concepts and approaches. These group members exchange their teaching experience and ideas in the same field. Fig. 1 and 2 are recorded activities of these two communities. The community members also have the same 
community in which the group members establish the relationship of mutual discussion, learning from each other, and sharing knowledge and information. The belonging sense of each community has been enhanced greatly. English learning and teaching isn't confined to the physical space of classroom, but instead, cyberspace connects the students and teachers closely and tightly.

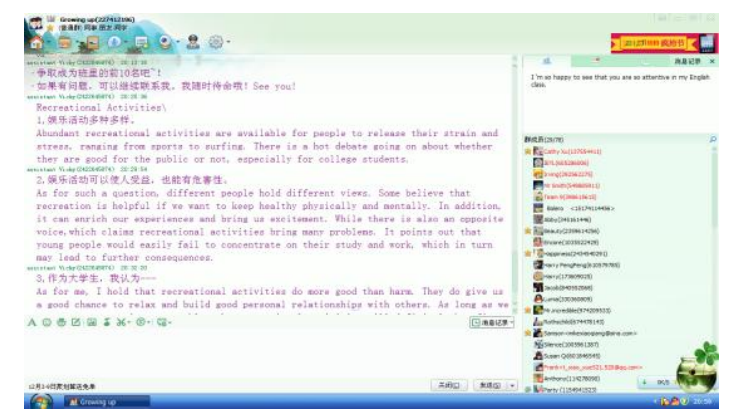

Fig.1: Group activity about CET 4 writing in Growing-up learning community.

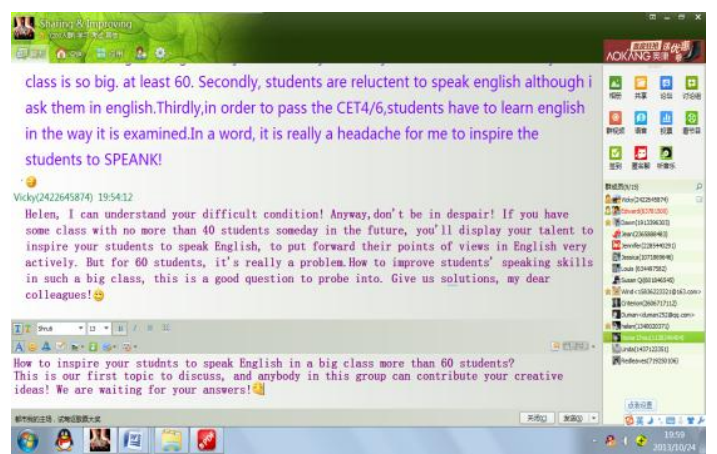

Fig.2: Interaction between Helen and Vicky, English teachers from two universities in Sharing \& Improving English Teaching community.

\section{B. Design of Three-stepped College English Teaching and Learning Model Oriented by Critical Problems Centred on Language and Cultural Issues}

Step 1: design and release of pre-class central questions. English teachers must understand grammatical, pragmatical, and cross-cultural knowledge very deeply before teaching a new unit. English teachers from English Teaching Community have to design language questions, focusing on inductive, appraisal and analytical abilities rather than simple and repeated imitation of the language, and cultural questions stressing appraisal, deductive and analytical ones in terms of cultural development, cutural characteristics, cultural comparison and cross-cultural communication. All these questions should match with five-skill training in deduction, induction, evaluation, reasoning, and analysis. The author takes the Integrated Course 2 of New College Englsih published by Shanghai Foreign Language Educaiton Press as an example, designing 5 language questions and 5 cultural counterparts as the pre-class learning tasks which necessarily cover the training of five thinking abilities. These questions are formed through heated discussion and cooperation of English Teaching Community. Each community member can put forward 10 relative questions, and then the qualified 10 ones are selected for release. Three days before learning the new unit, these well-chosen questions are uploaded onto the English Learning Community or other digital platform. Students conduct network preview of the text, self-search, deep-leveled thinking, and at last, the group discussion to form the group answers for each of questions.

Now let's take a close look at these 10 questions designed for Unit One: Learning: Chinese Style. Five questions for language issues are: What does the text begin with? Write down differences in approaches to learning between the Chinese and Americans; What's the function of the anecdote? How do you understand the "standing on the shoulders of giants" phenomenon? How does the author draw his conclusion in the end of the text? (How does the author wind up the text?). Five questions for cultural issues as follows: What did the Chinese colleagues think of the key-slot incident? What examples does the author give to illustrate childhood education in the arts of China? What does the author think of Teaching by Holding His Hand? How does the author think of the Chinese attitude towards creativity? What are the advantages and disadvantages of Eastern (Chinese) and Western (American) learning styles? Table 1 presents these 10 questions belonging to five particular training areas in induction, deduction, appraisal, reasoning, and analysis. Fig 3 and 4 record the releasing of these 10 questions characteristic of critical thinking training in English Learning Community and heated discussions among community members. 
TABLE 1:

PRE-CLASS QUESTIONS FOR LANGUAGE AND CULTURAL ISSUES IN LEARNING: CHINESE STYLE

\begin{tabular}{|l|l|l|}
\hline Abilities & Cuestions & Central Questions for Cultural Issues \\
\hline Inductive ability & What does the text begin with? & $\begin{array}{l}\text { What did the Chinese colleagues think of the } \\
\text { key-slot incident? }\end{array}$ \\
\hline Deductive ability & $\begin{array}{l}\text { Write down differences in approaches to } \\
\text { learning between the Chinese and } \\
\text { Americans. }\end{array}$ & $\begin{array}{l}\text { What examples does the author give to } \\
\text { illustrate childhood education in the arts of } \\
\text { China? }\end{array}$ \\
\hline Appraisal ability & What's the function of the anecdote? & $\begin{array}{l}\text { What does the author think of Teaching by } \\
\text { Holding His Hand? }\end{array}$ \\
\hline Reasoning ability & $\begin{array}{l}\text { How do you understand the "standing on } \\
\text { the shoulders of giants" phenomenon? }\end{array}$ & $\begin{array}{l}\text { How does the author think of the Chinese } \\
\text { attitude towards creativity? }\end{array}$ \\
\hline Analytical ability & $\begin{array}{l}\text { How does the author draw his conclusion } \\
\text { in the end of the text? } \\
\text { (How does the author wind up the text?) }\end{array}$ & $\begin{array}{l}\text { What are the advantages and disadvantages of } \\
\text { Eastern (Chinese) and Western (American) } \\
\text { learning styles? }\end{array}$ \\
\hline
\end{tabular}

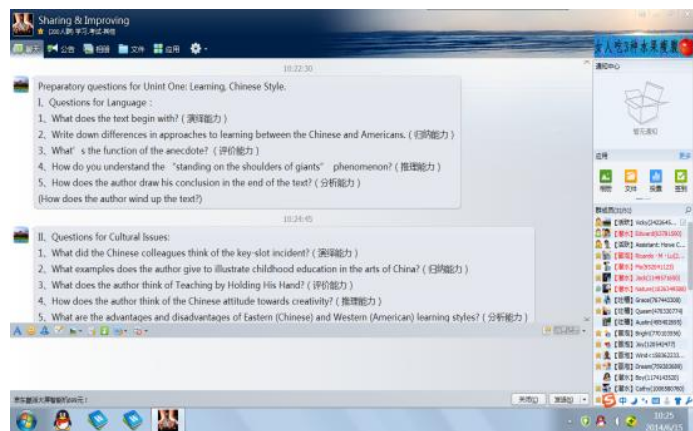

Fig.3: The release of 10 questions before learning Unit One: Learning: Chinese Style

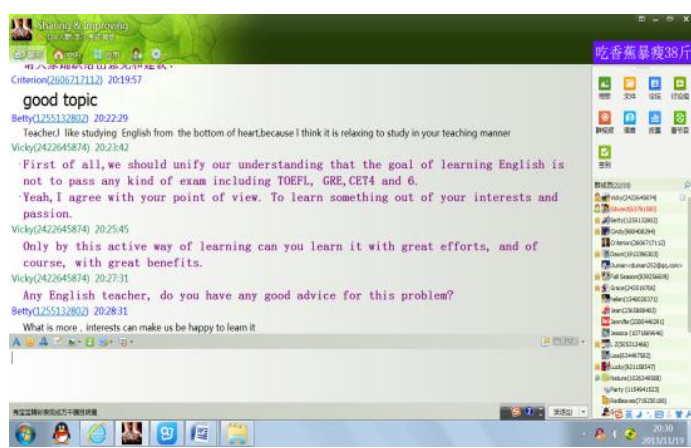

Fig.4: Heated discussions among community members centered around pre-class questions

Step 2: conducting in-class group collabrative learning through discussion and exploration. Students spent three days previewing the new lesson through multi-media including college network English learning platform, English Learning Community, micro-message group, English teachers' QQ Zone and micro-blogs to pre-learn the new learning materials thoroughly and deeply, providing the first-round answers for 10 questions reflecting critical thinking training through online communicaiton with their group members of 10 groups and also with English teachers in order to explore the deep-leveled connotation and significance of the questions. New questions will be taken into the class owing to the critical thinking about each question. In the English class, the students from 10 groups can discuss 10 questions freely and publicly (the number of the group members range from 2 to 6, Fig 5 is a good case in point). After group members put forward their points of views very actively, a goup representative will be invited to generalize their viewpoints. If the opinions meet with disagreements, then an open discussion comes into play. English teacher is the organizor, guide and evaluator in the process of this 3C's comprehensive training. College English class should be changed from a traditional situation that teacher teaches and students take notes answering simple and recurring questions which prevents higher-leveled thinking abilities. Instead, the students' creative and critical thinking about those pre-learning questions with discussion, answering, seraching for the optimum solutions, and presenting new questions has become the major frame of the new college English teaching and learning pattern. Under this new teaching model featured by self-exploration and group collabration, the teachers put more emphasis on training and developing the students' critical and creative thinking abilities through designing higher-levelled analytical questions which are the highest-level question for critical thinking. On teaching the new unit, the class oriented by analytical questions fulfill the thinking and exploring learning focusing on critical thinking, collabrative discussion and cross-cultural communicative abilities. 

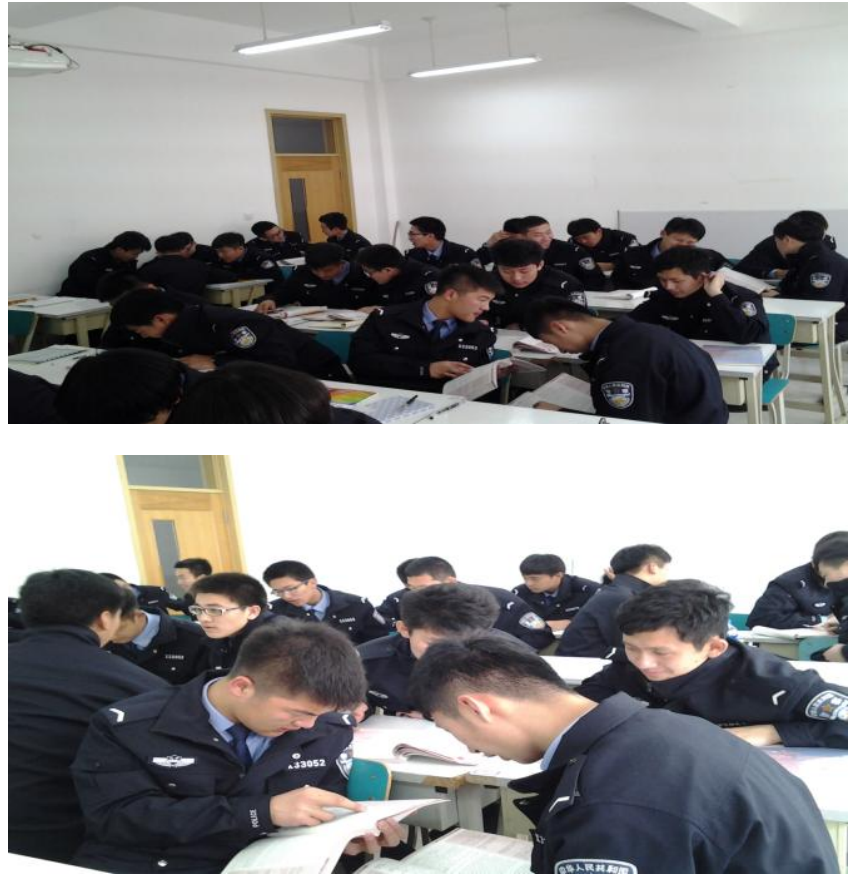

Fig.5: In-class group discussions about 10 pre-class questions in Class 2 Grade 1 of Criminal Technology Department

TABLE 2:

ANSWERS FOR PRE-CLASS QUESTIONS FOR LANGUAGE AND CULTURAL ISSUES IN LEARNING: CHINESE STYLE

\begin{tabular}{|l|l|l|}
\hline \multicolumn{1}{|c|}{ Answers } & $\begin{array}{l}\text { Answers for Central Questions for } \\
\text { language Issues }\end{array}$ & $\begin{array}{l}\text { Answers for Central Questions for Cultural } \\
\text { Issues }\end{array}$ \\
\hline $\begin{array}{l}\text { Inductive } \\
\text { ability }\end{array}$ & The text begins with an anecdote. & $\begin{array}{l}\text { Most of the colleagues displayed the same } \\
\text { attitude as the staff at the Jinling Hotel. }\end{array}$ \\
\hline $\begin{array}{l}\text { Deductive } \\
\text { ability }\end{array}$ & $\begin{array}{l}\text { (1) ways to learn to accomplish a task; } \\
\text { (2) attitudes towards creativity and skills }\end{array}$ & $\begin{array}{l}\text { (1) Children at the age of 5 or 6 painting } \\
\text { flowers, fish and animals skillfully; } \\
\text { (2) Calligraphers aged 9 or 10 can produce } \\
\text { excellent works. }\end{array}$ \\
\hline $\begin{array}{l}\text { Appraisal } \\
\text { ability }\end{array}$ & $\begin{array}{l}\text { It is directly relevant to the author's } \\
\text { assigned tasks in China including } \\
\text { investigating early childhood education } \\
\text { and comparing two learning styles. }\end{array}$ & $\begin{array}{l}\text { It can be applied to the mastering of the arts } \\
\text { which can take place by continual careful } \\
\text { shaping and molding. }\end{array}$ \\
\hline $\begin{array}{l}\text { Reasoning } \\
\text { ability }\end{array}$ & $\begin{array}{l}\text { It was first recorded in the 12 } \\
\text { and it was later famously used by Issac } \\
\text { Newton which means the reason why I } \\
\text { can see a litter further or achieve greater } \\
\text { success is that I stand on the shoulders } \\
\text { of Giants or I obtain the great essence } \\
\text { from previous theories and } \\
\text { achievements. }\end{array}$ & $\begin{array}{l}\text { They don't pay more attention to creativity } \\
\text { than Americans who put priority in developing } \\
\text { children's creativity at an early age. }\end{array}$ \\
\hline $\begin{array}{l}\text { Analytical } \\
\text { ability }\end{array}$ & $\begin{array}{l}\text { He winds up the text with a suggestion } \\
\text { in the form of a question rather than an } \\
\text { answer. }\end{array}$ & Open answers from different perspectives. \\
\hline
\end{tabular}

Step 3: Carrying out after-class network reflective learning through accomplishing Viewpoint Composition or Reflective Diary. The main purpose of writing these two kinds of compositions is to encourage the students to describe the concepts accurately, to cite the evidences effectively and to make the logical reasoning strictly. Once the students finish their writing assignment, they upload their products to the community of practice for four-dimension assessment including self-assessment, peer assessment, teachers' assessment, and public assessment. This kind of positive writing output is the profound reflection and wide expansion of the intensive reading, and this reflection and understanding of the new materials is the best approach to train students' critical thinking skill and their English cultural thinking. As to the text of Learning: Chinese Styles, the author assigned two topics for the students to write: The Optimum Way of Learning: from Chinese and American Perspective and Understanding of the Western and Eastern Education and Learning Approach. Fig. 6 is Zhou Fuhao's writing titled Creativity and Basic Skills e-mailed to his English teacher through QQ mailbox for the third dimension assessment. 


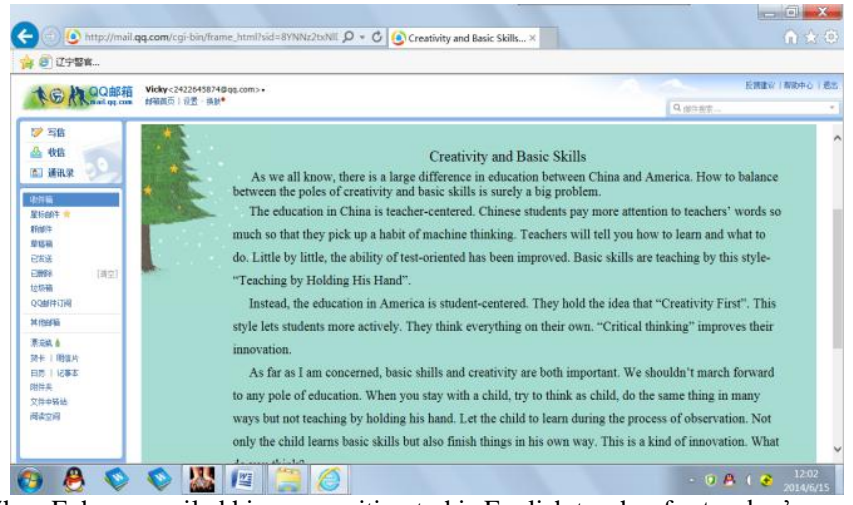

Fig.6: Zhou Fuhao e-mailed his composition to his English teacher for teacher's assessment.

\section{Creativity and Basic Skills}

As we all know, there is a huge difference in education between China and America. How to balance between the poles of creativity and basic skills is surely a big problem.

The education in China is teacher-centered. Chinese students pay more attention to teachers' words so much so that they pick up a habit of machine thinking. Teachers will tell you how to learn and what to do. Little by little, the ability of test-oriented has been improved. Basic skills are teaching by this style - "Teaching by Holding His Hand".

Instead, the education in America is student-centered. They hold the idea that "Creativity First". This style lets students more actively. They think everything on their own. "Critical thinking" improves their innovation.

As far as I am concerned, basic skills and creativity are both important. We shouldn't march forward to any pole of education. When you stay with a child, try to think as child, do the same thing in many ways but not teaching by holding his hand. Let the child to learn during the process of observation. Not only the child learns basic skills but also finish things in his own way. This is a kind of innovation. What do you think?

It's well-known to us that Chinese students tend not to think in critical manner, but rather, they tend to think in a middle way without direct disagreement or open discussion, which results in the shortage of creative talents with abundant critical thinking abilities. The unique three-step design of English teaching pattern oriented by critical thinking problems just compensates for this teaching deficiency. Although there are some mistakes or flaws in this viewpoint composition, we should admit that Zhou's critical thinking on learning approaches has been reflected through English teaching pattern oriented by critical problems. Maybe his critical thinking ability hasn't reached a high level, but we do believe that after long-term cultivation and regular training his critical thinking skill can be enhanced to the acme of perfection. This is only an initiative example of scores of writings aimed at developing students' critical thinking ability. So long as this English teaching pattern can be applied into the normal English class, turning into the normalized teaching pattern, we are reasonable to believe that most of the students will be equipped with critical thinking ability, learning to solve the problems with critical theory.

\section{CONCLUSIONS}

English teaching is a rather complicated cognitive activity. In the process of setting up the curriculum objectives, (Herrick, 1962) conducting teaching plans, (Taylor, 1970) designing learning tasks, (Mondol, 1973) taking part in teacher-to-student inter-activities, (Peterson, 1988) judging the students' learning problems, (Carbone, 1980) and fulfilling teaching assessment, (Johnson, 1972) English teachers must employ critical thinking skill to accomplish the above teaching goals. As far as critical thinking education is concerned, only English teachers possess sufficient critical thinking skill can they play an exemplary role for the students applying this kind of skill in their learning, (Mayfield, 2001) make an accurate judgment on the students' critical thinking skills, and adjust their teaching contents, teaching progress and strategies to ensure that the students' critical thinking abilities can be developed significantly. (Roy et al., 2005) To design an English lesson seriously full of appropriate critical thinking problems through pre-class questions release and discussion and after-class assessments for reflective writing assignments by means of online learning community of practice is a very effective and practical approach to train the college students' critical thinking skills in English network teaching and learning process in China.

\section{ACKNOWLEDGMENT}

The research is financed by the Twelfth Five-year Plan for Educational Science Project of Liaoning Province (2013) No. JG13EB053: On the Operation Mechanism of ESP Teachers' Online Learning Community, and by Teaching Research Project of Liaoning Police Academy (2013): A Study of the Multi-pattern EGP Teaching Research Based upon Cloud Technology, and also by College Teaching Reform Research Project of Liaoning Province (2014) No. UPRP20140574: Multi Models to Develop College Students' 3C Abilities through Network College English Teaching and Learning Based upon Questions. 


\section{REFERENCES}

[1] Beyer, B. (1988). Developing a thinking skills curriculum. Boston, MA: Allyn \& Bacon: 1.

[2] Carbone, P. F, Jr. (1980) Liberal education and teacher preparation. Journal of Teacher Education: 31(3) 7-12.

[3] Cheng Guangyun \& Xia Nianxin. (2012). Philosophical education as civilian education and dialogue education. Beijing: Chinese Social Science Press: 158.

[4] Cheng Xiaotang \& Kang Yan. (2010). Thinking on a few questions about college English teaching. Chinese College Teaching, (6): 40-44.

[5] Herrick V. E. (1962) Curriculum decisions and provision for individual differences. The Elementary School Journal: 62 (6) 313-320.

[6] Hu Wenzhong \& Sun Youzhong. (2006). Stressing the curriculum feature and strengthening humanistic education: an attempt to discuss the present English teaching reforms. Foreign Language Teaching and Research: (5) 243-247.

[7] Johnson, D. M. (1972). Systematic Introduction to the Psychology of Thinking. New York: Harper and Row.

[8] Mayfield, M. (2001). Thinking for yourself: developing critical thinking skills through reading and writing. London: Harcourt College.

[9] Mondol, M. M. (1973). The paramorphic representation of teacher decision making as a predictor of inquiry performance. East Lansing, MI: Michigan State University.

[10] Paul, R. (1988). Program for the Fourth International Conference on Critical Thinking and Educational Reform. Sonoma State University, Rohnert Park, CA.

[11] Peterson, P. L. (1988). Teachers' and students' cognitional knowledge for classroom teaching and learning. Educational Researcher: 17 (5)5-14.

[12] Roy, A. \& Macchiette, B. (2005). Debating the issues: a tool for augmenting critical thinking skills of marketing students. Journal of Marketing Education: 27 (3) 264-275.

[13] Ruan Quanyou. (2014). A Study on the Development of Students' Critical Literacy through the Communities of Practice on QQ Platform. Computer-assisted Foreign Language Education: (2) 48-53.

[14] Taylor, P. H. (1970). How teacher plan their courses. Slough, England: National Foundation for Educational Research in England and Wales.

[15] Vygotsky, L. S. (1978). Mind in Society: The development of higher psychological processes. Cambridge, MA: Harvard University Press.

[16] Wenger, E. (2002). Cultivation Communities of Practice: A Guide to Managing Knowledge. Boston Mass: Harvard Business School Press: 5.

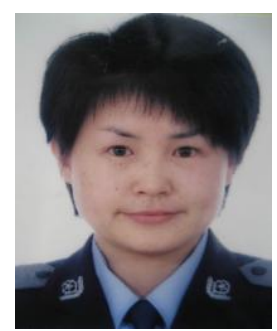

Li Wei, born in Feb. 1972 in Liaoyang, China. BA of English, Liaoning Normal University, 1993, Master of English, Liaoning Normal University, 2007. She is a professor in Liaoning Police Academy, the author of one EI indexed paper. She has published more than 40 papers in Chinese academic journals including World Ethno-national Studies, Shandong Social Sciences, Social Sciences in Xinjiang, Academy, and 20 English papers published in international journals and international conference proceedings. Her concentration centers around the Multicultural education, the Canadian Studies and network assisted Foreign Language Teaching.

Professor Wei is a candidate for the Police Liaison Officers of the Public Security Ministry of China. 